\title{
Hubungan Antara Psychological Well-Being dengan Loneliness Pada Lansia yang Tinggal di Panti Jompo di Kota Medan
}

\section{The Relationship Between Psychological Well-Being And Loneliness of The Elderly Who Stayed at Nursing Homes in Medan City}

\author{
Susanti(1)* ${ }^{*}$ Vera Veronica(2), Nadya Krisanta(3) \& Achmad Irvan Dwi Putra(4) \\ Fakultas Psikologi, Universitas Prima Indonesia, Indonesia \\ Disubmit: 14 Desember 2020; Diproses: 21 Desember 2020; Diaccept: 16 Maret 2021; Dipublish: 05 April 2021 \\ *Corresponding author: E-mail: susantiwuu97@gmail.com
}

\begin{abstract}
Abstrak
Tujuan dari penelitian ini adalah untuk mengetahui hubungan antara Psychological Well-Being dengan Loneliness pada Lansia yang Tinggal di Panti Jompo di Kota Medan. Hipotesis dalam penelitian ini yaitu terdapat hubungan negatif antara Psychological Well-Being dengan Loneliness pada Lansia yang Tinggal di Panti Jompo di Kota Medan. Subjek yang digunakan dalam penelitian ini adalah sebanyak 100 orang lansia yang menetap di panti jompo dengan menggunakan metode Purposive Sampling. Metode yang digunakan dalam penelitian ini adalah metode kuantitatif, pengumpulan data menggunakan skala Psychological Well-Being dan skala Loneliness masing-masing sebanyak 31 aitem. Uji asumsi yang digunakan dalam penelitian ini adalah uji normalitas dan uji linearitas. Data dianalisis menggunakan uji korelasi Pearson Product Moment dan SPSS 17 for Windows. Hasil analisis data menunjukkan adanya hubungan negatif antara Psychological Well-Being dengan Loneliness pada Lansia yang Tinggal di Panti Jompo di Kota Medan dengan koefisien korelasi Pearson Product Moment sebesar -0.654 dengan Sig $0.000(\mathrm{p}<0.005)$. Hasil penelitian juga menunjukkan bahwa sumbangan efektif yang diberikan variabel Psychological Well-Being terhadap Loneliness adalah sebesar 42,8 persen. Dari hasil penelitian yang didapatkan maka dapat disimpulkan bahwa hipotesis penelitian dapat diterima karena adanya hubungan negatif antara Psychological Well-Being dengan Loneliness.
\end{abstract}

Kata Kunci: Lansia; Loneliness; Psychological Well-Being

\begin{abstract}
The purpose of this reseacrh is to determine the relationship between Psychological Well-Being and Loneliness of the Elderly who stayed at nursing homes in Medan City. The hypothesis of this research is that there is a negative relationship between Psychological Well-Being and Loneliness of the Elderly who stayed at nursing homes in Medan City. The subjects that used in this research are 100 elderly who stayed in nursing homes with using the purposive sampling method. The method that used in this research is quantitative method, the data collected by using the Psychological Well-Being scale and the Loneliness scale which contains of 31 items each scale. The assumption tests that used in this research are the normality test and linearity test. Data were analyzed by using Pearson Product Moment correlation test with SPSS 17 for Windows. The results of the data analysis showed that there is a negative relationship between Psychological Well-Being and Loneliness of the Elderly who stayed at nursing homes in Medan City with the coefficient of Pearson Product Moment correlation -0.654 and Sig 0.000 ( $p<0.005)$. The results also showed that the effective contribution given by the Psychological Well-Being variable to Loneliness was 42.8 percent. From the research results, it can be concluded that the research hypothesis was accepted because there is a negative relationship between Psychological Well-Being and Loneliness.
\end{abstract}

Keywords: Elderly; Loneliness; Psychological Well-Being

DOI: https://doi.org/10.51849/i-p3k.v2i1.77

Rekomendasi mensitasi :

Susanti, Veronica, V., Krisanta, N., \& Putra, D.I.A. 2021. Hubungan Antara Psychological Well-Being dengan Loneliness Pada Lansia yang Tinggal di Panti Jompo di Kota Medan. Jurnal Penelitian Pendidikan, Psikologi dan Kesehatan (J-P3K), 2 (1): 20-27. 


\section{PENDAHULUAN}

Setiap orang pasti akan mengalami proses pertumbuhan dan perkembangan dalam kehidupannya dimulai dari masa kanak-kanak, masa remaja, masa dewasa hingga lanjut usia. Seiring bertambahnya usia, individu juga akan mengalami penuaan yang merupakan proses alami dalam siklus kehidupan yang sering ditandai dengan menurunnya berbagai fungsi organ tubuh pada sistem pencernaan, pernapasan, pembuluh darah, jaringan kulit, dan persendian (Dewo, 2013). Proses penuaan ini umumnya terjadi pada masa lanjut usia.

Menurut Festi (2018), lanjut usia adalah tahap terakhir perkembangan pada kehidupan manusia yang dimulai dari usia 60 tahun hingga hampir mencapai 120 atau 125 tahun. Sedangkan menurut Aryono \& Dani (2019) lansia adalah kategori manusia yang telah memasuki tahapan akhir dari periode kehidupan. Dalam Undang-Undang Negara Republik Indonesia Nomor 13 Tahun 1998 yang membahas tentang kesejahteraan lanjut usia juga dipaparkan bahwa lanjut usia adalah individu yang memiliki usia diatas 60 tahun.

Lebih lanjut dibahas mengenai lanjut usia potensial adalah lansia yang masih dapat melakukan suatu kegiatan atau aktivitas yang bisa menghasilkan suatu barang atau jasa, sedangkan lanjut usia tidak potensial adalah lansia yang sudah tidak memiliki kemampuan untuk mencari nafkah sehingga hanya dapat bergantung pada bantuan keluarga atau orang lain disekitarnya.

Dalam survei yang dilakukan oleh Badan Pusat Statistik (BPS) terhadap penduduk lanjut usia tahun 2019 , tercatat bahwa persentase penduduk lansia di Indonesia meningkat dua kali lipat dalam kurun waktu 48 tahun yaitu dari tahun 1971 sampai tahun 2019. Pada tahun 2019, jumlah lansia mencapai sekitar 25,64 juta orang. Hal ini memperlihatkan bahwa lebih dari 7 persen keseluruhan penduduk Indonesia yang berusia lansia sedang mengalami proses menuju ke arah penuaan. Fenomena ini merupakan gambaran dari meningkatnya angka harapan hidup penduduk Indonesia.

Selama masa hidupnya, lansia juga tidak terlepas dari tiga masalah pokok yang kerap dihadapi para lansia yaitu, pertama adalah melemahnya fisik yang mengakibatkan lansia tidak dapat beraktifitas seaktif dulu lagi. Kedua, tidak jarang seorang lansia dapat mengalami kesepian karena hilangnya kontak atau hubungan dengan orang-orang terdekat maupun yang disayangi. Ketiga, post power syndrome yaitu lansia yang baru saja pensiun, kehilangan pangkat, pendapatan dan gengsi (Utami, 2018).

Seperti yang dituturkan oleh seorang subjek berinisial A yang berusia 61 tahun dan telah menetap di panti jompo selama kurang lebih 3 tahun berikut,

"Awal-awal waktu baru tinggal disini, ada rasa tidak nyaman, rasanya ingin balik saja, tapi karena anak saya mau ke luar kota bekerja, tidak ada orang lagi, terpaksa saya harus tinggal disini. Anak saya juga setahun sekali baru datang".

Sedangkan saat ditanya tentang bagaimana perasaan subjek sekarang, subjek menjawab sebagai berikut:

"Ya kalau sekarang sudah terbiasa. Ada kawan-kawan juga, bisa ibadah bersama".

Di sisi lain, subjek berinisial $\mathrm{H}$ yang telah menetap di panti jompo selama 5 
tahun masih merasakan kesedihan dan kehilangan karena ditinggalkan oleh keluarganya. Subjek mengatakan:

"Saya dibawa anak saya kemari, katanya orang di rumah semuanya sibuk, tidak ada yang bisa menjaga saya. Jadi, saya dititipkan disini, tapi sampai sekarang tidak ada yang datang melihat saya".

Para lansia yang mengalami berbagai penurunan atau kemunduran secara jasmani maupun rohani dapat mempengaruhi mobilitas dan juga interaksi sosial lansia tersebut. Kemunduran tersebut menimbulkan rasa terkucilkan, tersisihkan, tidak dipedulikan, terisolasi dari lingkungan, tidak ada tempat berbagi cerita, sehingga menyebabkan para lansia merasakan kesepian atau loneliness, terutama bagi lansia yang menetap di panti jompo dan hanya sesekali atau bahkan tidak pernah dikunjungi oleh keluarga maupun sanak saudaranya.

Menurut Hunt (2013), kesepian atau loneliness merupakan suatu kondisi kesedihan yang disebabkan oleh perasaan terisolasi ataupun terpisah dari orang lain. Sedangkan menurut Bhagchandani (2017) kesepian adalah suatu perasaan negatif subjektif yang dirasakan oleh seseorang karena memiliki hubungan sosial yang kurang. Dapat disimpulkan bahwa kesepian atau loneliness adalah perasaan negatif berupa kesedihan yang dirasakan oleh seseorang akibat kurangnya atau bahkan tidak adanya interaksi yang berarti dengan orang lain maupun orang disekitarnya.

Weiss (dalam Sherman, 2012) menyebutkan bahwa kesepian terdiri dari dua jenis yaitu: (a) Emotional Loneliness, yaitu saat individu merasakan kehilangan figur lekat berupa pasangan, kekasih, orangtua, maupun anak. (b) Social Loneliness, terjadi saat individu merasakan kurangnya hubungan atau interaksi sosial dengan orang lain. Misalnya pindah ke lingkungan yang baru, pindah kerja, tidak dianggap oleh kelompok dan tidak termasuk dalam sebuah kelompok.

Dilansir dari Cnnindonesia.com, rasa kesepian dapat memangkas harapan hidup lansia. Ketika seorang lansia tidak punya seseorang untuk diajak berbicara, waktu mereka hanya dihabiskan dengan melamun ataupun berbaring di kamar tidur sehingga lansia tersebut tidak melakukan aktivitas fisik apapun. Hal ini dapat menyebabkan obesitas dan gangguan fisik lain pada lansia. Dampak lainnya, kondisi kesehatan jiwa para lansia juga dapat terganggu dimana, kesepian tersebut dapat merusak otak yang sama seperti otak seseorang yang merokok (Detikhealth.com).

Dampak negatif tersebut dapat diatasi apabila seseorang memiliki sikap positif terhadap diri sendiri yang dicerminkan melalui Psychological WellBeing yaitu dimana individu tersebut dapat menerima kelemahan dan kelebihan yang ada dalam dirinya, mandiri, dapat menentukan pilihannya sendiri, dapat menjalin hubungan yang baik dengan orang lain, mampu memodifikasi lingkungannya, memiliki tujuan hidup dan terus mengembangkan pribadinya seperti yang dipaparkan Ryff (Hartato et al., 2018).

Ryff (Ramadhani et al., 2016) juga mendefinisikan konsep Psychological Well-Being dalam enam dimensi yaitu penerimaan diri, hubungan positif dengan 
orang lain, otonomi, penguasaan lingkungan, tujuan hidup, dan pertumbuhan pribadi. Selain itu, Wells (Rosalina, 2018) memaparkan faktorfaktor yang dapat mempengaruhi Psychological Well-Being antara lain umur, gender, status pernikahan, status sosialekonomi, hubungan sosial, komunitas, aktivitas fisik, penyakit, penuaan, dan kepribadian.

Ada banyak faktor yang dapat mempengaruhi Psychological Well-Being seseorang, salah satunya adalah Loneliness. Pada hasil penelitian yang dilakukan oleh peneliti sebelumnya Halim \& Dariyo (2016) dimana terdapat hubungan negatif yang signifikan antara Psychological Well-Being dengan Loneliness dengan data yang diperoleh adalah korelasi antara Psychological WellBeing dan Loneliness $(\mathrm{r}=-0.659 ; \mathrm{p}=0.000$ $<0.005$ ).

Hipotesis penelitian ini adalah adanya hubungan negatif antara Psychological Well-Being dengan Loneliness pada lansia yang tinggal di Panti Jompo di Kota Medan. Dimana semakin tinggi Psychological Well-Being, maka semakin rendah Loneliness dan sebaliknya semakin rendah Psychological Well-Being, maka semakin tinggi Loneliness individu tersebut.

Berdasarkan uraian di atas, peneliti tertarik untuk melakukan penelitian dengan judul "Hubungan Antara Psychological Well-Being dengan Loneliness pada Lansia yang Tinggal di Panti Jompo di Kota Medan" dengan rumusan masalah sebagai berikut: (1) Apakah terdapat hubungan antara Psychological Well-Being dengan
Loneliness? (2) Bagaimana Psychological Well-Being mempengaruhi Loneliness?

Tujuan dari penelitian ini adalah untuk mengetahui dan membuktikan hubungan antara Psychological Well-Being dengan Loneliness pada lansia yang tinggal di panti jompo di Kota Medan. Manfaat dari penelitian ini yaitu sebagai penambah wawasan dalam ilmu pengetahuan berdasarkan pada teori-teori yang ada, khususnya dalam bidang Psikologi, penelitian ini juga diharapkan dapat memberikan pandangan mengenai Psychological Well-Being pada lansia, khususnya yang mengalami kesepian serta dapat dimanfaatkan sebagai referensi untuk penelitian selanjutnya.

\section{METODE PENELITIAN}

Metode penelitian yang digunakan peneliti adalah penelitian kuantitatif. Menurut Sugiyono (2018), penelitian kuantitatif adalah suatu metode pada penelitian yang mengacu pada positivisme yang digunakan dalam meneliti suatu sampel ataupun suatu populasi.

Sugiyono (2018) menjelaskan populasi merupakan area keseluruhan yang didalamnya terdapat subjek atau objek yang mempunyai kriteria tertentu yang ditetapkan untuk dipelajari oleh peneliti, sedangkan sampel adalah bagian dari jumlah populasi.

Populasi yang akan diteliti adalah lansia yang tinggal di panti jompo di Kota Medan yakni Panti Jompo Yayasan Guna Budi Bakti, Yayasan Pemenang Jiwa, Yayasan Taman Bodhi Asri. Sampel yang hendak diteliti dalam penelitian ini yakni sebanyak 100 orang lansia dari panti jompo tersebut. Adapun variabel-variabel dalam penelitian ini adalah Psychological 
Well-Being sebagai variabel bebas dan Loneliness sebagai variabel terikat.

Teknik pengambilan sampel menggunakan Purposive Sampling yang pengambilan datanya berdasarkan kriteria-kriteria yang telah ditentukan. Adapun kriteria subjek yang ditentukan adalah lansia dengan usia 60 tahun keatas, sudah menetap di panti jompo minimal 1 tahun, dan mampu untuk berpartisipasi dalam pengisian kuesioner.

Metode pengumpulan data menggunakan skala Psychological WellBeing dan skala Loneliness. Pernyataanpernyataan yang telah disusun dalam skala kemudian diukur menggunakan skala Likert yang digunakan sebagai pengukur pendapat, sikap, serta persepsi seseorang tentang fenomena yang terjadi.

Pada skala Psychological Well-Being, variabel yang diukur berdasarkan dimensi-dimensi yang didefinisikan oleh Ryff (Ramadhani et al., 2016) yaitu penerimaan diri, hubungan positif dengan orang lain, otonomi, penguasaan lingkungan, tujuan hidup, dan pertumbuhan pribadi. Skala terdiri dari 48 aitem pernyataan, 24 aitem favourable dan 24 aitem unfavourable.

Pada skala Loneliness yang terdiri dari 40 aitem pernyataan yang terbagi menjadi 20 aitem favourable dan 20 aitem unfavourable yang disusun berdasarkan variable yang dijelaskan oleh Weiss (dalam Sherman, 2012) yakni kesepian emosional dan kesepian sosial.

Alat ukur berupa skala Psychological Well-Being dan skala Loneliness harus terlebih dahulu diuji tingkat validitas dan reliabilitas pada setiap aitem pernyataan sebelum digunakan dalam penelitian. Menurut Sugiyono (2018), validitas adalah mengukur sesuatu yang harus diukur (ketepatan), sedangkan reliabilitas adalah mengukur berkali-kali tetap menghasilkan hasil yang sama (konsisten). Penelitian ini menggunakan teknik reliabilitas Alpha Cronbach yaitu teknik dalam penelitian yang digunakan untuk menguji reliabilitas.

Sebelum dilakukan analisa data, terlebih dahulu dilakukan uji asumsi yang terbagi menjadi uji normalitas dan uji linearitas. Teknik dalam menganalisis data yang digunakan adalah teknik korelasi Pearson Product Moment yaitu suatu teknik korelasi yang bertujuan untuk menguji dan membuktikan apakah ada hubungan antara variabel-variabel dalam penelitian dan juga memberitahu kita kemana arah hubungan dari kedua variabel tersebut, baik positif maupun negatif.

\section{HASIL DAN PEMBAHASAN}

Metode untuk menganalisis data yang digunakan dalam penelitian ini adalah metode korelasi Pearson Product Moment menggunakan bantuan SPSS Statistic 17 for windows. Metode ini digunakan untuk mengetahui Hubungan Antara Psychological Well-Being dengan Loneliness pada Lansia yang Tinggal di Panti Jompo di Kota Medan.

Analisis menggunakan teknik korelasi Pearson Product Moment. Berdasarkan hasil analisis diperoleh nilai Pearson Correlation sebesar - 0.654 dengan Sig sebesar 0.000 ( $\mathrm{p}<0.05$ ). Hal tersebut menunjukkan adanya korelasi negatif antara variabel Psychological WellBeing dengan Loneliness dan dikategorikan memiliki korelasi yang kuat. Dari hasil ini maka dapat dinyatakan bahwa hipotesis diterima dimana terdapat 
hubungan negatif antara Psychological Well-Being dengan Loneliness pada Lansia yang Tinggal di Panti Jompo di Kota Medan. Berikut tabel hasil uji korelasi Pearson Product Moment.

Tabel 1. Uji Korelasi Pearson Product Moment

\begin{tabular}{lll}
\hline Analisis & $\begin{array}{l}\text { Pearson } \\
\text { Correlation }\end{array}$ & Signifikansi (p) \\
\hline Korelasi & -.654 & 0.000 \\
\hline
\end{tabular}

Berdasarkan tabel 2, nilai $R$ square $=$ 0.428. Dari nilai tersebut dapat disimpulkan bahwa Psychological WellBeing memberikan sumbangan efektif sebesar 42,8 persen terhadap Loneliness dan sisanya 57,2 persen dipengaruhi indikator lain yang tidak diteliti.

Tabel 2. Sumbangan Efektif

\begin{tabular}{ccc}
\hline Model & $\mathrm{R}$ & R Square \\
\hline 1 & -.654 & .428 \\
\hline
\end{tabular}

Hasil dari penelitian yang dilakukan kepada 100 orang lansia yang menetap di Panti Jompo di kota Medan menunjukkan bahwa adanya hubungan negatif antara Psychological Well-Being dengan Loneliness dengan nilai Pearson correlation sebesar -0.654 dengan Sig sebesar $0.000(\mathrm{p}<0.05)$. Maka dari hasil tersebut dapat kita ketahui bahwa semakin tinggi Psychological Well-Being seseorang, maka semakin rendah tingkat Loneliness nya dan begitu pula sebaliknya, semakin rendah Psychological Well-Being, maka semakin tinggi Loneliness seseorang tersebut.

Seseorang dengan Pyschological Well-Being atau bisa juga disebut dengan kesejahteraan psikologis yang baik, pada umumnya memiliki penerimaan diri yang baik, yaitu menerima kelemahan dan kelebihan diri, dan merasa positif tentang kehidupan yang telah dijalani. Hal ini dapat dilihat dari mayoritas lansia merasa bahwa masa lalu mereka sangat berharga dan dapat menerima kekurangan diri mereka masing-masing serta memiliki tujuan hidup yang baik dibuktikan dengan menghargai pengalaman yang dilalui dan merasa memiliki kehidupan yang bermakna.

Selain itu, sebagian lansia juga mampu mengambil keputusan sendiri yang merupakan salah satu ciri dari otonomi yang baik yaitu mampu untuk menentukan tindakan sendiri, tetapi dalam penguasaan lingkungan, terkadang para lansia sulit beradaptasi dengan lingkungannya dikarenakan tidak adanya kegiatan yang dapat dilakukan sehingga menyebabkan lansia-lansia tersebut mudah merasa bosan.

Pertumbuhan pribadi pada lansia yang berarti kemampuan lansia untuk mengembangkan kemampuan yang ada pada diri secara terus menerus juga dapat dilihat dari banyaknya lansia yang masih bersemangat untuk melakukan hal-hal yang mereka suka, namun cenderung kurang semangat untuk mempelajari halhal yang baru.

Di sisi lain, lansia juga masih senang berinteraksi dan berbagi dengan orang sekitar yang menunjukkan bahwa lansia tersebut memiliki hubungan baik dengan orang lain. Dengan kemampuan untuk membentuk hubungan yang baik dengan orang di sekitarnya, kebanyakan lansia dengan Psychological Well-Being yang baik sukar merasakan kesepian atau Loneliness karena lansia tersebut memiliki orang untuk berbagi dan dapat dengan mudah 
menyuarakan pendapatnya tanpa merasa terhalang atau terabaikan.

Hal tersebut dapat terlihat ketika para lansia suka berbagi cerita dengan temannya mengenai pengalaman yang terjadi serta para lansia mau saling membantu jika ada lansia lain yang sedang perlu bantuan. Sebaliknya, orang dengan Psychological Well-Being yang rendah akan sangat mudah merasakan kesepian karena orang tersebut mudah putus asa, merasa ditinggalkan dan tidak ada yang mau mendengar, sulit mengendalikan emosi, dan pada akhirnya cenderung mengasingkan diri.

Pembahasan diatas sejalan dengan hasil penelitian dari Bhagchandani (2017) yaitu terdapat hubungan negatif yang signifikan antara Psychological Well-Being dan Loneliness dimana, semakin tinggi Loneliness semakin rendah pula Psychological Well-Being, pada penelitian tersebut juga dinyatakan bahwa tidak ada hubungan yang signifikan antara jenis kelamin dengan kedua variabel tersebut.

Tidak berbeda jauh dengan hasil penelitian dari Halim \& Dariyo (2016) dimana semua aspek pada Psychological Well-Being mempunyai hubungan negatif dan signifikan dengan perasaan Loneliness. Berdasarkan hasil uraian di atas, dapat disimpulkan bahwa terdapat hubungan negatif yang signifikan antara Psychological Well-Being dan Loneliness, jadi penting bagi seseorang untuk memiliki Psychological Well-Being yang tinggi agar tidak mudah merasakan kesepian. Karena kesepian bukanlah hal yang bagus bagi kesehatan mental seseorang.

\section{SIMPULAN}

Berdasarkan hasil yang telah didapatkan dari penelitian ini, maka dapat disimpulkan bahwa ada hubungan negatif antara Psychological Well-Being dengan Loneliness dengan nilai koefisien korelasi Pearson Product Moment sebesar -0.654 dan $\mathrm{p}=0.000$ serta faktor Psychological Well-Being berpengaruh terhadap Loneliness sebesar 42,8\%.

Dimana, semakin tinggi Psychological Well-Being para lansia, maka semakin rendah Loneliness lansia tersebut. Begitu sebaliknya, semakin rendah Psychological Well-Being, maka semakin tinggi Loneliness yang dirasakan oleh para lansia tersebut.

Psychological Well-Being yang baik sendiri bisa terlihat pada lansia berupa penerimaan diri yang baik, mampu mengambil keputusan sendiri, mau mengembangkan potensi, memiliki hubungan yang baik dengan lingkungan sekitar, penguasaan lingkungan, dan adanya tujuan hidup.

\section{DAFTAR PUSTAKA}

Aryono, M., \& Dani, R. (2019). Loneliness and Psychologiwal Well Being Among Elderly. Proyeksi, 14(2), 162-171.

Bhagchandani, R. K. (2017). Effect of Loneliness on the Psychological Well-Being of College Students. International Journal of Social Science and Humanity, 7(1), 60-64.

Bps.go.id. (2019, 20 Desember). Statistik Penduduk Lanjut Usia 2019. Diakses pada 25Februari2020.

https://www.bps.go.id/publication/2019/1 2/20/ab17e75dbe630e05110ae53b/statisti k-penduduk-lanjut-usia-2019.html

Cnnindonesia.com. (2019, 22 Maret). Studi: Kesepian Bisa Memangkas Harapan Hidup Lansia. Diakses pada 25 Februari 2020. https://m.cnnindonesia.com/gayahidup/20 190319145218255378730/studi-kesepianbisa-memangkas-harapan-hidup-lansia. 
Detikhealth.com. (2016, 19 April). Pada Lansia, Kesepian Sama Buruknya Seperti Merokok dan Obesitas.

Diakses pada 25 Februari 2020. https://m.detik.com/health/beritadetikhealth/d3191299/padalansiakesepiansama-buruknya-seperti-merokok-danobesitas

Dewo, M. (2013). Gendola: Obat Dewa Penakluk Aneka Penyakit. Jakarta: FMedia.

Festi, P. (2018). Lanjut Usia Perspektif dan Masalah. Surabaya: UMSurabaya Publishing.

Halim, C. F., \& Dariyo, A. (2016). Hubungan Psychological Well-Being dengan Loneliness pada Mahasiswa yang Merantau (Relationship between Psychological WellBeing and Loneliness among Overseas Student). Jurnal Psikogenesis, 4(2), 170-181.

Hartato, I., Basaria, D., \& Patmodewo, S. (2018). Terapi Well-Being Untuk Meningkatkan Psychological Well-Being Pada Remaja Yang Tinggal Di Panti Sosial Bina Remaja X. Psibernetika, 10(1), 20-29.

Hunt, J. (2013). Loneliness: Hope for The Heart. California: Aspire Press.

Ramadhani, T., Djunaedi, \& S, A. S. (2016). Kesejahteraan Psikologis ( Psychological Well- Being ) Siswa Yang Orangtuanya Bercerai. Bimbingan Konseling, 5(1), 108-115.

Rosalina, R. (2018). Hubungan Antara Psychological Capital Dengan Psychological Well-Being Pada Dokter Muda Fakultas Kedokteran Universitas Diponegoro. Empati, 7(3), 291-296.

Sherman, E. (2012). Working With Older Persons: Cognitive and Phenomenological Methods. Berlin: Springer Science \& Business Media.

Sugiyono. (2018). Metodologi Penelitian Kuantitatif, Kualitatif, dan R\&D. Bandung: Penerbit Alfabeta.

Utami, R. J. (2018). Faktor-faktor Yang Mempengaruhi Loneliness pada Para Lanjut Usia di Wisma Cinta Kasih Padang. Jurnal Ilmiah Ilmu Terapan Universitas Jambi, 2, 121. 